Eur. J. Clin. Chem. Clin. Biochem.

Vol. 32, 1994, pp. 355-359

(C) 1994 Walter de Gruyter \& Co.

Berlin · New York

\title{
Synthesis of a Non-Radioactive Hepatitis B Virus DNA Probe from Human Serum by the Polymerase Chain Reaction ${ }^{1}$ )
}

\author{
By F. Rodriguez-Frias, J. A. Arranz, M. Buti, R. Esteban and R. Jardi \\ Liver Unit, Departments of Biochemistry and Hepatology, Hospital General Vall d'Hebron, Barcelona, Spain
}

(Received July 15, 1993/January 3, 1994)

Summary: A method for synthesizing probes for detecting hepatitis B virus DNA in serum was developed. It uses DNA extracted from the serum of an hepatitis B virus carrier as target, and digoxigenin-11-dUTP incorporated in DNA sequences during the polymerase chain reaction as tracer.

Using a spot hybridization assay, the sensitivity and specificity of the digoxigenin-labelled DNA probe were compared with two standard hepatitis B virus DNA probes, synthesized with cloned hepatitis B virus DNA and labelled either with digoxigenin or ${ }^{32} \mathrm{P}$ by random priming. Data obtained from the three methods showed an excellent correlation.

Thus, hepatitis B virus DNA extracted from human serum and labelled by polymerase chain reaction may be considered a suitable alternative to cloned DNA. It provides reliable probes and eliminates the need for facilities and personnel dedicated to the manipulation of clones. These advantages will allow a wider application of hepatitis $B$ virus DNA testing in clinical practice.

\section{Introduction}

The detection of hepatitis B virus DNA in serum by spot-blot hybridization is an indication of viral replication and correlates with the patient's infectivity and hepatic inflammatory activity $(1-3)$. Although the widely-used detection of DNA by isotopic probes is highly sensitive, its use in clinical diagnosis is limited economically by the need for special facilities. For this reason, non-isotopic probes have been proposed as an alternative (4). Recently, à new non-radioactive system was developed, which uses digoxigenin for labelling DNA probes (5-6). Digoxigenin can be incorporated into a fragment of DNA by random priming or during the polymerase chain reaction (7). This last method has the advantage that DNA from serum may be used as target (8) instead of cloned DNA, because the specificity of the polymerase chain reaction allows the amplifi-

\footnotetext{
') This work was supported in part by a grant from the Fondo de Investigaciones de la Seguridad Social (FIS-92-1309)
}

cation of the desired DNA fragment from an heterogeneous mixture of serum DNAs.

In this report we describe a method for synthesizing specific DNA probes which use DNA extracted from the serum of an hepatitis B virus carrier as target, and digoxigenin-11-2'-deoxyuridine-5'-triphosphate (digoxigenin-11-dUTP) incorporated during polymerase chain reaction, as tracer. We compare the results obtained with this probe with those obtained with two hepatitis $B$ virus DNA probes (both from Eco RI fragment isolated from pCF80 plasmid containing four copies of cloned hepatitis $B$ virus DNA), labelled either with digoxigenin or ${ }^{32} \mathrm{P}$ by random priming, in serum samples from patients with chronic hepatitis $\mathrm{B}$.

\section{Materials and Methods}

Patients

Two groups of subjects were studied:

Group 1 included 150 patients with chronic B hepatitis, $60 \mathrm{HBeAg}$ positive and 90 anti-HBe positive. The diagnosis of chronic hepa- 
titis was based on cvidence of persistent alteration in hepatic tests for longer than six months, and the presence of chronic hepatitis in an histological exannination.

Group II consisted of 30 healthy blood donors without serological markers of hepatitis $B$ virus infection.

\section{Serological assays}

Sera were evaluated for $\mathrm{HBsAg}$, anti-HBs, anti-HBc, $\mathrm{HBeAg}$, and anti-HBe by commercial radioimmunoassay kits: Ausria-II, Ausab, Corab, Abbott $\mathrm{HBe}$ (Abbott Laboratories, North Chicago, IL).

\section{Purification and DNA labelling by polymerase chain} reaction

Hepatitis B virus DNA was purified and extracted from serum samples as previously described (9): digestion with proteinase $\mathrm{K}$, and extraction with phenol (once) and with chloroform/isoamylalcohol (twice). Subsequently, the hepatitis B virus DNA was precipitated with ethanol in the presence of sodium acetate. For the polymerase chain reaction assay, a set of sequences 20 nucleotides long, specific for the hepatitis B virus pre-core/core region, was synthesized and used as primers: Primer 1765, 5'TCTTTGTACTAGGAGGCTGT begins at position 1765 of the hepatitis B virus genome and primer 2458, 5'CTAACATTGAGATTCCCGAG (from the complementary or reverse DNA strand) begins at map position 2458 (10). The size of the amplified product is 694 base pairs. The polymerase chain reaction was performed according to the protocol of Saiki et al. (11) with some modifications. Reactions were carried out in a volume of $100 \mu \mathrm{l}$ containing at least $10-20 \mathrm{pg}$ of hepatitis B virus DNA from serum, $200 \mu \mathrm{mol} / \mathrm{l}$ of each deoxynucleotide triphosphate (dATP, dCTP, dGTP) including dTTP $(165 \mu \mathrm{mol} / \mathrm{l})$ partially substituted with digoxigenin-11-dUTP $(35 \mu \mathrm{mol} / \mathrm{l}), 50$ pmol of each primer and $2.5 \mathrm{U}$ of Taq thermostable polymerase (Boehringer Mannheim), in a buffer containing $50 \mathrm{mmol} / 1 \mathrm{KCl}, 10$ $\mathrm{mmol} / \mathrm{l} \mathrm{Tris}-\mathrm{HCl}(\mathrm{pH} 8.3)$ and $1.5 \mathrm{mmol} / 1 \mathrm{MgCl}_{2}$. The reaction was performed for 35 cycles $\left(1 \mathrm{~min} 94^{\circ} \mathrm{C}, 1 \mathrm{~min} 60^{\circ} \mathrm{C}\right.$ and $3 \mathrm{~min}$ $72^{\circ} \mathrm{C}$ ) in a programmable DNA Thermal Cycler (Perkin Elmer Cetus). The specificity of the amplified product was confirmed by Southern blot hybridization, using ${ }^{32} \mathrm{P}$ labelled hepatitis $\mathrm{B}$ virus DNA (isolated from pCF80) as probe. The sensitivity of the digoxigenin DNA probe was determined by testing decreasing dilutions (500 to $0.5 \mathrm{pg}$ ) of plasmid DNA pCF80 in duplicate. As negative control, plasmid pBR322 at a concentration of $200 \mathrm{pg}$ was used.

To confirm the gene-specificity of the probe, another specific probe from the Pre-S/S region was synthesized by a similar procedure, and a crossed-hybridization experiment was designed in which three parallel polymerase chain reaction techniques were used to amplify three different hepatitis B virus DNA fragments: one from the Pre-core/core region (694 base pairs), another from the Pre-S/S gene ( 567 base pairs) and a third which included a combination of both regions $\left(1.9 \times 10^{3}\right.$ base pairs). After Southern blot transfer, all three amplification products were hybridized separately with each specific probe. Serum samples from healthy subjects who tested negative for hepatitis B virus markers were used as controls.

\section{DNA labelling by random priming}

Hepatitis B virus DNA $(0.3 \mu \mathrm{g})$ from cloned hepatitis B virus DNA pCF80 plasmid, kindly provided by Dr. C. Brechot, Paris, (containing four entire copies of hepatitis B virus genome inserted in the Eco RI position) was labelled by random priming incorporation of digoxigenin-11-dUTP (Boehringer Mannheim) or ${ }^{32} \mathrm{P}$ (Amersham Corporation) following the manufacturer's instructions.

The rate of labelling was tested in the non-isotopic probes by serial dilutions of each probe spotted on nylon membrane, followed by colour reaction.

\section{Hepatitis B virus DNA assay}

The spot-blot hybridization technique described by Scotto et al. (3) for the detection of hepatitis B virus DNA was used with minor modifications (12). Seven microlitres of each sample were directly denatured in $0.5 \mathrm{~mol} / 1 \mathrm{NaOH}, 1.5 \mathrm{mmol} / \mathrm{l} \mathrm{NaCl}$ for $10 \mathrm{~min}$, and transferred by vacuum to a nylon membrane (Hybond-N. Amersham). The nylon filters were always prehybridized for at least $2 \mathrm{~h}$ in $12.5 \mathrm{~mol} / 1$ formamide, saline/sodium citrate $(0.75 \mathrm{~mol} / 1 \mathrm{NaCl}$, $0.075 \mathrm{~mol} / \mathrm{l}$ Na-citrate), $0.02 \mathrm{~mol} / \mathrm{l}$ Na-phosphate $(\mathrm{pH} 6.5$ ), Denhardt's solution ( $0.1 \mathrm{~g} / \mathrm{l}$ Ficoll (type 400 , Pharmacia), $0.1 \mathrm{~g} / \mathrm{l}$ polyvinylpyrrolidone and $0.1 \mathrm{~g} / 1$ bovine serum albumin (fraction $\mathrm{V}$, Sigma)) and $100 \mathrm{mg} / \mathrm{l}$ salmon sperm DNA at $42^{\circ} \mathrm{C}$. Hybridization was carried out in the same solution with either $100 \mu \mathrm{g} / \mathrm{l}$ of non-radioactive probe or $10 \mu \mathrm{g} / \mathrm{l}$ of radioactive probe.

The positive hybridization with digoxigenin-labelled probes was visualized by enzyme-linked immunoassay using an antibody-conjugate (antidigoxigenin alkaline phosphatase conjugate) and nitroblue tetrazolium/5-bromo-4-chloro-3-indolyl-phosphate as colour substrates following the supplier's instructions (Boehringer Mannheim) (6). Positive hybridizations with the radioactive probe was detected by autoradiography $\left(14 \mathrm{~h}\right.$ at $\left.-70^{\circ} \mathrm{C}\right)$ with Kodak XAR-S film and Micron $R$ intensifying screen.

The sensitivity of the two probes synthesized with cloned hepatitis $\mathrm{B}$ virus DNA is $0.5 \mathrm{pg}$ as previously described (12).

\section{Results}

\section{DNA labelling by polymerase chain reaction}

The polymerase chain reaction products were analysed by agarose gel electrophoresis. The fragment obtained without digoxigenin produced a clear band of 694 base pairs corresponding to the expected length of the amplified region. The lower electrophoretic mobility of the polymerase chain reaction products with digoxigenin indicated that his hapten had been incorporated into the DNA fragment with a resulting increase in molecular mass (fig. 1). The differences in mobility between the normal and the digoxigenin-labelled polymerase chain reaction fragments permit an approximate estimate (derived from a semilogarithmic representation of mobility vs. molecular mass, using the molecular mass markers for the standard curve) of the number of hapten molecules incorporated (11-12 per probe molecule). This estimate may be utilized as a first control to validate the labelling process, in addition to the above described dilution method. The dilution method detected up to $10^{-6}$ dilutions of the original polymerase chain reaction probe solution.

\section{Specificity and sensitivity of the serum} hepatitis B virus DNA probe synthesized by polymerase chain reaction

The specificity of the polymerase chain reaction probes was tested by dot and Southern blot hybridization, using previously tested samples, which were positive for $\mathrm{HBeAg}$ and hepatitis $\mathrm{B}$ virus. $\dot{\mathrm{D} N A}$, as positive controls. 


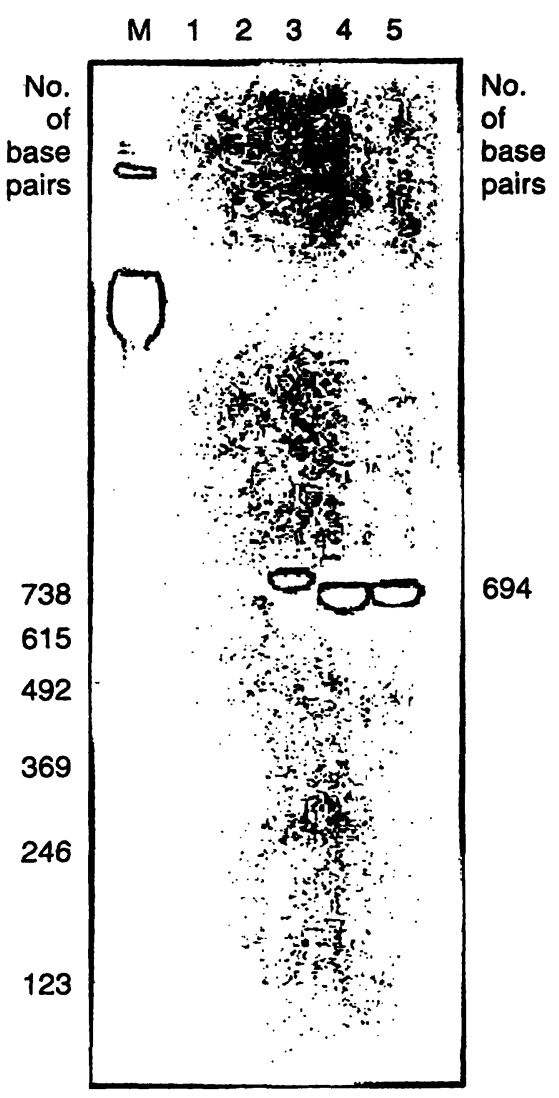

Fig. 1 Ethidium bromide staining of amplified bepatitis B virus DNA.

Left: DNA markers, 123 ladder (Life Technologies. BRL).

Lanes 1-3: Digoxigenin polymerase chain reaction probes using different amounts of target DNA (20,40 and 100 pg respectively). Lanes 4 and 5: Polymerase chain reaction products from hepatitis $B$ virus DNA extracted from two different serum samples without incorporation of digoxigenin in the polymerase chain reaction mixture.

Patients from group II were used as negative controls. None of the negative controls produced positive signals. Some examples are shown in figure 2 (absence of hybridization signals in the negative lanes of Southern blots) and in figure 3 (coordinates e1, e2, e3 and e4 of dot blots).

The specific probes labelled with digoxigenin for the Pre-core/core and Pre-S/S regions hybridized exclusively with the amplification products of their respective regions. In neither case was cross-hybridization observed. Moreover, both probes hybridized with the large amplified hepatitis B virus DNA fragment that included the two regions. Neither of the two probes hybridized with the negative controls (fig. 2).

Using spot test hybridization, the digoxigenin polymerase chain reaction-labelled probe detected as little as $0.5 \mathrm{pg}$ of cloned hepatitis B virus, which is comparable to the sensitivity obtained with random priming probes (12).

\section{Comparison of hybridization results}

The results from the serum digoxigenin polymerase chain reaction incorporated probe were compared with results from the cloned hepatitis $B$ virus DNA probes labelled either with digoxigenin or ${ }^{32} \mathrm{P}$ by random priming. Hepatitis B virus DNA was determined by spot hybridization in the serum of $150 \mathrm{HBsAg}$ positive patients. Hepatitis B virus DNA was detected in $68(45 \%)$ of the $150 \mathrm{HBsAg}$ positive serum specimen patients: fifty four (90\%) from $\mathrm{HBeAg}$ positive chronic hepatitis patients, and fourteen $(15 \%)$ from anti-HBe positive, with all three methods. None of the 30 samples from the healthy subjects was positive for hepatitis B virus DNA by any of the three techniques. In some samples with positive hybridization signals the observed intensity was higher in the non-radioactive methods than the radioactive one, showing additionally a slightly different colour from that expected. Sometimes it was necessary to overexpose a filter in order to assure the presence of weak hybridization signals. As an example of the hybridization comparison, figure 3 shows a dot blot experiment including a sample group of patients randomly selected from the study population.

\section{Discussion}

The synthesis of DNA probes from human serum using the polymerase chain reaction technique has not been described previously. In this study, DNA extracted from the serum of hepatitis $B$ virus carriers was used as the target. By including a modified nucleotide with digoxigenin as the tracer in the amplification mixture of a standard polymerase chain reaction, specific non-radioactive probes for determining hepatitis B virus DNA by spothybridization were produced.

In the dot blot experiments (see fig. 3) the results obtained with serum probes are the same as those obtained with the standard probes with respect to the subsequent clinical decision (i. e. positivity or negativity). In some samples, however, differences in the intensity of the hybridization signals were observed between the radioactive and the non-radioactive probes, the latter giving more intense signals than the former. These anomalous signals present a slightly different colour from those remaining, which may have been produced by some unknown interference present in the original serum samples. The results obtained in the Southern blot experiment confirmed the expected specificity of the serum polymerase chain reaction probes and disclosed a characteristic property of polymerase chain reaction probes (from serum or cloned DNA) that can be called "sequence-specificity", based on the ability of the polymerase chain reaction process to produce concrete DNA 
A 1

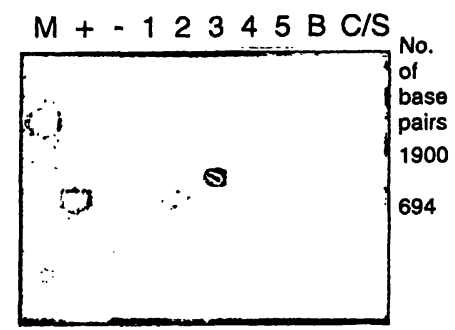

B 1

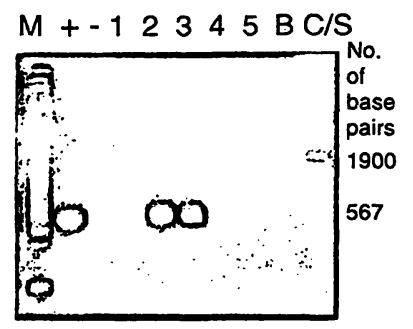

A 2

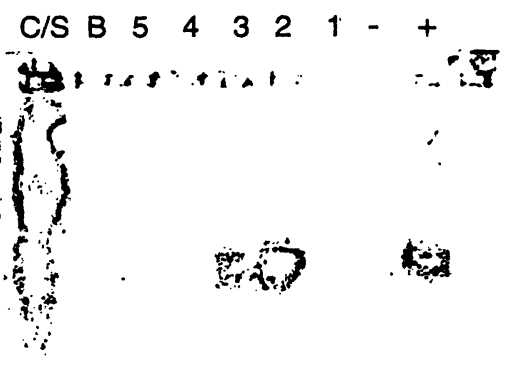

A 3
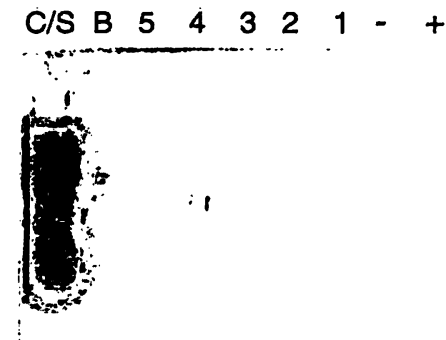

B 3

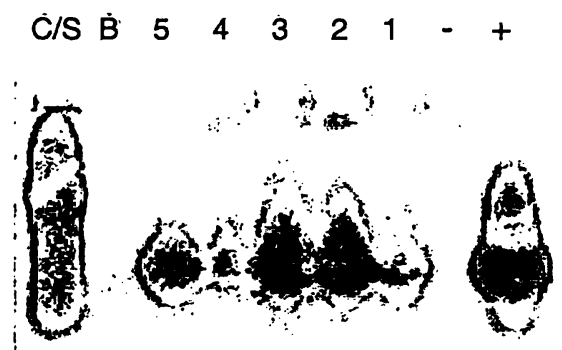

Fig. 2 Specificity of the hepatitis B virus DNA polymerase chain reaction serum probe.

Al Ethidium bromide staining of amplified fragment from Pre core/core.

A2 Hybridization of the Pre core/core polymerase chain reaction products with the Pre core/core specific probe.

A3 Hybridization of the Pre core/core polymerase chain reaction products with the Pre S/S probe.

B1 Ethidium bromide staining of polymerase chain reaction products from Pre S/S.
B2 Hybridization of Pre S/S polymerase chain reaction products with a Pre core/core probe.

B3 Hybridization of Pre S/S polymerase chain reaction products with a Pre S/S probe.

M: Molecular mass markers, 123 Ladder (BRL).

+ : Positive control.

-: Negative control.

Lanes 1-5: Random samples from the $\mathrm{HBsAg}$ positive patient group.

C/S: Hybridization control: $1.9 \times 10^{3}$ base pairs fragment including Pre core/core and Pre S/S regions.
A

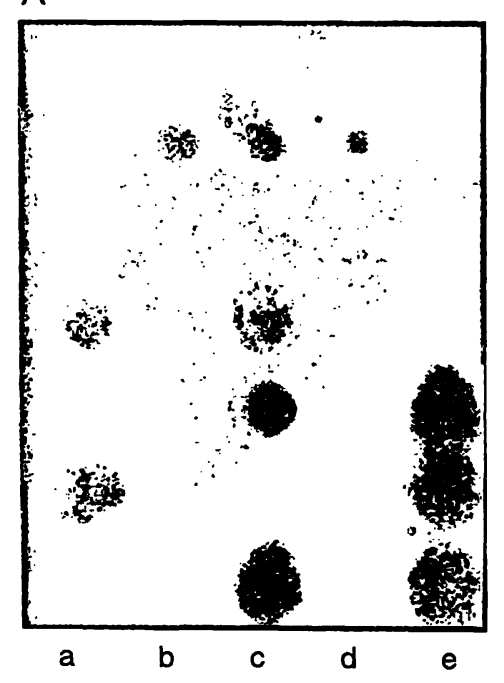

$B$

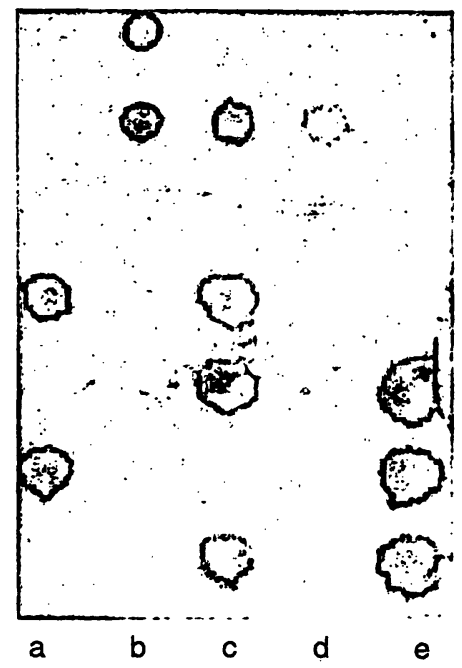

C

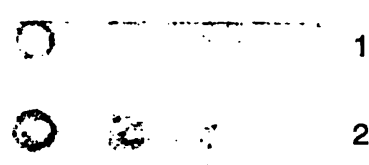

3

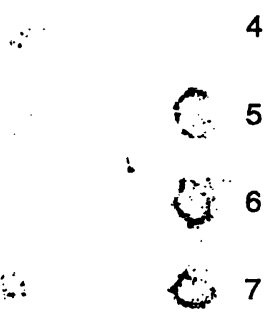

a b c c d e 
fragments defined by the selected set of primers. We demonstrated this property in the experiment shown in figure 2. A possible application of this property could be the study of which genes are present in the partially inserted hepatitis B virus DNA sequences observed within the hepatocyte genome of asymptomatic hepatitis $B$ virus carriers or in hepatocellular carcinomas. Such a study could be carried out using subcloned fragments of hepatitis $B$ virus DNA as gene-specific probes, but the protocol would be much more complex than in the method suggested above.

These results demonstrate that the sensitivity, specificity and analytical applications of these probes are the same as those of conventional probes, prepared with cloned DNA. Since they are synthesized with an amplification process specific for a sequence of target DNA, the serum probes may be used for detecting complete genomes, as well as a particular sequence in heterogeneous DNA mixtures.

The described method offers a number of methodological advantages over the conventional techniques presently used. The characteristics of the polymerase chain reaction reaction permit the use of DNA from hepatitis $B$ virus DNA present in the serum of an $\mathrm{HBsAg}$-positive

\section{References}

1. Brechot, C., Hadchouel, M., Scotto, J., Degos, F., Charnay, P., Trepo, C. \& Tiollais, P. (1981) Detection of hepatitis B virus DNA in liver and serum: A direct appraisal of the chronic carrier state. Lancet 2, 765-767.

2. Bonino, F., Hoyer, B., Nelson, J., Engle, R., Verme, G. \& Gerin, J. (1981) Hepatitis B virus DNA in sera of HBsAg carriers: A marker of active hepatitis $B$ virus replication. Hepatology $I, 386-391$.

3. Scotto, J., Hadchouel, M., Hery, C., Yvart, J., Tiollais, P. \& Brechot, C. (1983) Detection of hepatitis B virus DNA in serum by a simple spot hybridization technique: Comparison with results for other viral markers. Hepatology 3, 279-284.

4. Larzul, D., Thiers, V., Courouce, A. M., Brechot, C. \& Guesdon, J. L. (1987) Non-radioactive hepatitis B virus DNA probes for detection of HBV-DNA in serum. J. Hepatol. 57, $199-204$

5. Casacuberta, J. M., Jardí, R., Buti, M., Puigdomenech, P. \& Sansegundo, B. (1988) Comparison of different nonisotopic methods for hepatitis B detection in human serum. Nucleic Acids Res. 16, 11834.

6. Holtke, H. J., Seibl, R., Burg, J., Muhlegger, K. \& Keßler, C. (1990) Non-radioactive labelling and detection of nucleic acids: II Optimization of the digoxigenin system. Biol. Chem. Hoppe-Seyler 37l, 929-938.

7. Lyon, T. \& Hass, O. (1990) Non-radioactive labelling of probe with digoxigenin by polymerase chain reaction. Anal. Biochem. $188,335-337$. patient, despite the complexity of this serum DNA, which is a mixture of viral and human DNAs. Labelling with digoxigenin permits the synthesis of large quantities of probe which may be stored at least one year without losing activity. Moreover, this non-radioactive method avoids the inconveniences of radioactive isotopes which have short half-lives and are difficult to handle in a routine diagnosis laboratory.

Finally, the technology necessary for synthesizing this type of probe is simple and may be easily implemented in the clinical laboratory. The need for specialized equipment, trained personnel and the extra time to carry out molecular biology techniques such as cloning, cellular transformation or vector amplification, is completely eliminated.

The results obtained from this study suggest that digoxigenin-labelled serum DNA probes may be a valid and practical alternative to probes obtained from cloned DNA.

\section{Acknowledgement}

The authors with to thank Montserrat Gimferrer, Carmen Molinos and Isabel Guilera for their nursing assistance.
8. Rodríguez, F., Buti, M., Jardí, R., Arranz, J. A., Esteban, R. \& Guardia, J. (1991) Nonradioactive labelling of HBV-DNA from human serum by PCR (Abstract). J. Hepatology 13 (suppl) S64.

9. Genescá, J., Jardí, R., Buti, M., Vives, L., Prat, S., Esteban, J. I. \& Guardia, J. (1987) Hepatitis B virus replication in acute hepatitis B virus-hepatitis, delta virus coinfection and acute hepatitis delta superinfection. Hepatology 7, 659-572.

10. Ono, Y., Onda, H., Sasada, H., Igarashi, K., Sugino, Y. \& Nishioka, K. (1983) The complete nucleotide sequences of the cloned hepatitis $\mathrm{B}$ virus DNA, subtype adr and adw. Nucleic Acids Res. 11, 1747-1757.

11. Saiki, R. K., Gelfand, D. H., Stoffel, S., Scharf, J., Higuchi, R., Horn, G. T., Mullis, K. B. \& Erlich, H. A. (1988) Primerdirected enzymatic amplification of DNA with thermostable DNA polymerase. Science $239,487-491$.

12. Buti, M. Jardi, R., Rodriguez-Frías, F., Arranz, J. A., Casacuberta, J. M., Sansegundo, B., Puigdomenech, P., Esteban, R. \& Guardia, J. (1991) Digoxigenin-labelled DNA-probe: A rapid, non-radioactive method for hepatitis B virus DNA detection in serum. Eur. J. Clin. Chem. Clin. Biochem. 29, 731-735.

Rosendo Jardí

Servicio de Bioquímica

Hospital General Valle de Hebrón

Paseo Valle de Hebrón $s / n$

Barcelona 08035

Spain 
